\title{
The Concept of Célmaine in Blathmac's Second Poem
}

\author{
Siobhán Barrett
}

\begin{abstract}
This paper presents a discussion on the significance of the word célmainde/ célmaine in the second of Blathmac's poems. Its significant position within the first verse is compared with occurences of this word within other texts, leading to the suggestion that célmainde may be used to describe the poem type.
\end{abstract}

Keywords: Early-Irish language, religious poetry, Irish poetry.

\author{
Siobhán Barrett \\ Early Irish (Sean-Ghaeilge) \\ Maynooth University \\ siobhan.barrett@mu.ie
}

The poems of Blathmac son of Cú Brettan consist of two long eighth-century Old Irish, religious poems preserved in a seventeenth-century manuscript (National

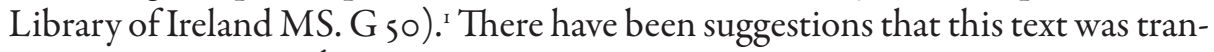
scribed by Mícheál Ó Cléirigh or one of his school of scribes, based on the fact that in the early I80os it was in the possession of John O'Clery, who claimed to be a descendant of one of the Four Masters and also claimed that the manuscript

This article was written as part of the IRC postgraduate scholarship 'New edition and dictionary of the poems of Blathmac son of Cú Brettan' at Maynooth University (Project ID GOIPG/20I4/448). I am grateful to David Stifter and the editors of Peritia for reading drafts of this article and for their suggestions for improvements. I also thank Liam Breatnach and Elizabeth Boyle, examiners of my $\mathrm{PhD}$, for their recommendations. I alone am responsible for any errors that remain.

- The manuscript can be viewed online at http://www.isos.dias.ie. A print edition of stanzas I-259 has been published by James Carney (ed \& trans), The poems of Blathmac, son of Cü Brettan, ITS 47 (Dublin 1964). A transcription of stanzas 260-303 is published in Nessa Ní Shéaghdha (ed), 'The poems of Blathmhac: the "fragmentary quatrains"', Celtica 23 (1999) 227-30: 227. All the quotations from Blathmac's poems that appear in this article are taken from the version of the poems that forms part of my PhD thesis. This version, which differs substantially from Carney's in wording and in spelling practice, is openly accessible at a stable institutional repository. Siobhán Barrett, $A$ study of the lexicon of the poems of Blathmac son of Cú Brettan; unpublished $\mathrm{PhD}$ thesis, Maynooth University (2017) 198-228, online at http://eprints.maynoothuniversity.ie/10042. This version includes stanzas 260-303, which are not included in Carney's edition. For a further revised edition of stanzas 260-303, see Siobhán Barrett \& David Stifter, 'Blathmac's stanzas 260-303 on Judgement Day', Celtica 3 I (2019) 19-89. 
was once the property of Mícheál Ó Cléirigh. ${ }^{2}$ The manuscript was purchased by the National Library in I93I and the poems were rediscovered in 1953 by Nessa Ní Shéaghdha. ${ }^{3}$ When James Carney's edition and translation was published by the Irish Texts Society in 1964, it was welcomed as a significant addition to the corpus of Irish literature. In 2014, to mark the fiftieth anniversary of the publication of Carney's edition, the subject of the Irish Texts Society's annual seminar was 'The Poems of Blathmac', from which resulted the publication of the important volume, The poems of Blathmac son of Cú Brettan: reassessments. ${ }^{4}$

Although the sole manuscript in which the poems are preserved dates from the seventeenth century, Blathmac, son of Cú Brettan son of Congus, was of the population group known as the Fir Rois (in present-day Co. Monaghan). His father, who was ruler of that people, had some part in the Battle of Allen (AU s.a. 722) and died in 740 (Cu Bretan m. Congusso moritur, $\mathrm{AU}$ ). The poems may therefore be dated to $c .750$. Both poems are religious in content and both are addressed to Mary the mother of Christ. The first poem contains I 49 stanzas. Because of the poor condition of the last few pages of the manuscript and the possibility that some pages may have been completely lost it is impossible to be certain how many stanzas the second poem originally contained. The last two pages of the manuscript are fragmentary, but by comparing the size of existing pieces against the layout of entire pages it would seem that there were at least I54 stanzas in the second poem. The first of Blathmac's two poems has generally been considered a keen.' At the most basic level, the first poem describes the birth, life and especially the death of Christ. The theme of keening is carried right through the poem, as demonstrated by thirteen instances of the verb coinid 'to keen' and eight occurrences of the verbal noun coiniud act of keening. ${ }^{6}$ Many other words associated with grief, crying, death and misery are peppered throughout the first poem. It is rooted in earthly human concerns and emotions, life on earth, pain, flesh, blood, death, mourning. In contrast to this, the second poem is rich with the language of life, and everlasting life at that. The purpose of the first poem, if not a complete keen in itself, is at least a call for the performance of a keen. But what about the purpose of the second poem? Is it possible to decipher what its purpose is by analysing possible clues in its words?

2 Carney, Poems of Blathmac, $\mathrm{x}$.

${ }^{3}$ David Stifter, 'The language of the poems of Blathmac', in Pádraig Ó Riain (ed), The poems of Blathmac son of Cú Brettan: reassessments (Dublin 2015) 47-103: 47.

${ }^{4}$ Ó Riain, The poems of Blathmac son of Cú Brettan.

' James Carney 'Poems of Blathmac, son of Cú Brettan', in James Carney (ed), Early Irish poetry. Thomas Davis Lectures (Cork 1965) 44-57: 46, reprinted in Robert McNally (ed), Old Ireland (NY 1965) 147-72; Brian Lambkin, 'The structure of the Blathmac poems', Studia Celtica 20-2I (1985) 67-77:67.

${ }^{6} \mathrm{eDil}$ s.v. cainid, online at dil.ie/7839. 
The word célmainde (1.598) in the first stanza is intriguing. It appears three times in the second of Blathmac's poems (11. 598, 746, 76I) but not at all in the first. ${ }^{7}$ James Carney translated it as 'mystic utterance' in the first two instances and 'announcement' in the third, which is apt in the context but at odds with the primary definition of the word in the Royal Irish Academy's Dictionary of the Irish Language (electronic version) eDIL: 'augury, omen, presage, prognostication, prophecy'. ${ }^{8}$ Carney proposed that the spelling célmoinde (MS. celboindi) that is found in NLI G 50 is probably an attempt to disguise the bad rhyme with clainde (MS. cloinne) in stanza 150. ${ }^{9}$ Its occurrence in the very first stanza of the second poem (= stanza I5O of the continuous numeration of Blathmac's two poems) is noteworthy. In the first poem the poet uses the word coiniud in the opening stanza and this sets the tone for the entirety of the first poem. Coiniud (1.2) by virtue of its position could be seen as a signal for the audience, indicating the purpose of the poem. So, could the word célmaine, occupying a similarly prominent position, possibly be a key to understanding the message or purpose of the second poem? Even a comparison of the vocabulary of the two initial stanzas demonstrates the contrast between the two poems. The tone of the first poem is death and sadness, epitomised by coiniud 'keen' and dirsan 'woe'.

Tair cucum, a Maire boid,

do choiniud frit do rochoim.

Dirsan dul fri croich dot mac,

ba mind már, ba masgérat.

(Poem 1, 11. 1-4)

Come to me, tender Mary,

for the keening with you of your very dear one.

Woe (is) the going to the cross by your son,

he was a great emblem, he was a fine hero. ${ }^{10}$

The tone of the second poem is more optimistic, featuring expressions such as scél maith 'good story', bithbéo 'eternally alive', and bithflaith 'eternal prince'.

A Maire, a grian ar clainde,

a mba moi mo chélmainde

do mac coinsimmar — scél maith! sech is bithbé, is bithflaith.

(Poem 2, 11. 597-600)

\footnotetext{
7 Barrett, $A$ study, 213, 216, 217.

${ }^{8}$ eDIL s.v. célmaine, online at dil.ie/8566.

9 Carney, Poems of Blathmac, I4I.

10 Barrett, A study, 198 .
} 
Mary, sun of our children,

when my célmainde was mine, we keened your son - good news -

yet, he lives eternally, he is an eternal prince. ${ }^{11}$

In this opening stanza of the second poem the first two verbs are in the past tense, mba (copula, 3sg past) and coinsimmar ('to keen', ipl preterite), so it is clear that the poet is referring to a past event when he keened Mary's son along with her. It is likely that this is referring to the first poem, or possibly to some keening event that has happened in the past, perhaps as a result of his appeal to Mary in the first poem. This is the only reference to keening in the second poem, thus linking it to the preceding text; but then the poet switches to the present tense in the last line of this stanza and tells Mary that all is good and that her son is eternally alive and is now prince in heaven. The keening is over, the poet is now on to something new. Could this new topic actually be the célmaine?

Two other occurrences of célmainde appear in stanzas 187 and 191,

Ni scél n-eris deit in sé, is creiti a célmainde.

Is iar n-eiséirgiu Christ gil

at.chuäid dia apstalaib.

(11. 745-48)

This is no heretical tale for you, the célmainde is to be believed.

it is after the resurrection of bright Christ

that he told it to his apostles. ${ }^{12}$

Is ed mo chélmainde nglé:

is ri do mac na nemdae, is ai grian asa gel tlacht, is ai a n-éscae n-étracht.

$$
\text { (11. 761-64) }
$$

This is my clear célmaine: your son is king of the heavens,

"Barrett, $A$ study, 213.

${ }_{12}$ Barrett, $A$ study, 216. 
his is the sun whose garment is bright,

his is the shining moon. ${ }^{13}$

In order to examine the possibility that célmaine performs a similar function in the second poem as coiniud did in the first one it is essential to attempt to understand what it may have meant to an audience in the eighth century. In eDIL, the headword célmaine is first of all defined as 'augury, omen, presage, prognostication, prophecy.' ${ }^{14}$ None of these meanings fits the passages in our poem. It also offers the secondary meaning 'utterance or saying', closer to the context of this poem, but this is actually based on the attestations found in Blathmac, and thus is circular for our present purposes. We need to take a closer look at the word and its attestations. Bernhard Bauer includes the word célmaine in his dissertation on Intra-Celtic loanwords as a possible loanword into Irish from British Celtic; for example Welsh coelfain 'gift, present, reward; object of desire; ... good news, gospel, evangel; joy'. It has been proposed that, because of the long é in the first syllable, this word must have been borrowed into Irish at the latest in the mid-eighth century, before the original monophthong ${ }^{*} \bar{\varepsilon}$ was diphthongised to $o$ in British. This is also the time that the poems of Blathmac are thought to have been composed. Blathmac made use of several other rare and, occasionally, innovative British loanwords, some of which are not found in other Irish texts. ${ }^{16}$ Because of the poet's creative use of language and the occurrence of other British words it would not be extreme to suggest that Blathmac may have been, if not the first, then one of the earliest to use the word célmainde in Irish.

Because of the religious subject matter of the poem, Blathmac has many opportunities to refer to Old Testament prophets and prophecies, but in these cases the verb he uses for the act of prophesying is do.airngir and the verbal noun tairchetal.

tairrngert Bálam mac Bëóir

which Balaam, son of Beor had prophesied

Do.rairngred do.n-icfed dé

ind flesc do chlaind Iëse.

(11. 401-02)

13 Barrett, $A$ study, 217.

${ }^{14}$ eDIL s.v. célmaine, online at dil.ie/8566.

is Bernhard Bauer, Intra-Celtic loanwords; unpublished PhD thesis (Vienna 2015) 21.

${ }^{16}$ See Stifter, 'The language of Blathmac', 97. The number of British loanwords identified in Blathmac's poems has increased in the meantime. 
It had been prophesied that there would come from it the scion of the plant of Jesse.

Is cian do.rairngred in sé, no.mbithe int augaire

(11. 505-06)

Long has this been prophesied, that the shepherd would be struck down.

Is i in briathar builid blaith
do.rairngert Dauid riofáith.

(11. 753-54)

This is the beautiful gentle word

that David, the king-prophet, had prophesied.

Is flaith do maic cen tláithi

do.rairrngertat primfáithi.

Ciaso sain labrad cach fir,

inunn rún a tairchetail.

(11. 925-28)

It is the kingdom of your son without weakness

that your chief prophets have prophesied.

Although the speech of each man is special,

the mystic meaning of their prophecy is the same. ${ }^{17}$

Célmaine, on the other hand, is used in a different context within Blathmac's poems, disconnected from the prophets of the Old Testament. He uses it to describe the words that he, the poet, is speaking. To Blathmac, at least, there is a distinction in meaning between tairchetal and célmaine. In an effort to understand the use of célmaine by Blathmac, other attestations of this word have been collected and examined within their context and below is a list of the relevant texts: ${ }^{18}$

${ }_{17}$ Barrett, $A$ study, 1. 46, 199; 11. 40I-02, 208; 11. 505-06, 210; 11. 753-54, 217; 11. 925-26, 221.

${ }_{18}^{18}$ Not all of these attestations are discussed in detail here. Derivatives of célmaine, such as the compound michélmaine, the adjective célmainech, the nouns célmainecht and célmanaigtheóir, and the verb célmainigid will not be discussed here. 
- Blathmac's Second Poem, eighth-century, verse ${ }^{19}$

- Colum Cille co Dia dom eráil, seventh- to eighth-century, verse ${ }^{2 \circ}$

- Talland Étair, ninth-century, prose and verse ${ }^{2 \mathrm{I}}$

- Scéla Cano meic Gartnáin, ninth-century, prose and verse ${ }^{22}$

- Cath Maighe Léna, thirteenth-century compilation of texts, some elements of the text may be earlier, prose and verse ${ }^{23}$

- In Cath Catharda, ninth- to twelfth-century, prose ${ }^{24}$

- Metrical Dindshenchas, Druim Fingin II $^{25}$

- Betha Mochuda, eleventh- to thirteenth-century, prose ${ }^{26}$

- Incipit do Scélaib na nDruad, fifteenth-century prose ${ }^{27}$

- Togail na Tebe, fifteenth-century, prose ${ }^{28}$

- The Gaelic abridgment of the Book of Ser Marco Polo, fifteenth-century, prose ${ }^{29}$

- Imtheachta Eniasa, fifteenth-century, prose ${ }^{30}$

- Cath Muighe Tuireadh, sixteenth-century, prose ${ }^{31}$

- Christ's Five Wounds, seventeenth-century, verse ${ }^{32}$

- Tochmarc Fearbhlaide, seventeenth-century, prose ${ }^{33}$

- Beatha Aodha Ruaidh Ui Dhombnaill, seventeenth-century, prose ${ }^{34}$

19 Barrett, A study, 213-28.

${ }^{\circ}$ Thomas Owen Clancy \& Gilbert Márkus (eds \& trans), Iona, the earliest poetry of a Celtic monastery. (Edinburgh I995) I70.

${ }^{21}$ Caoimhín Ó Dónaill (ed \& trans), Talland Étair: a critical edition with with introduction, translation, bibliography, textual notes and vocabulary (Maynooth 2005).

${ }_{22}$ Daniel Anthony Binchy (ed), Scéla Cano meic Gartnáin. Medieval \& Modern Series II (Dublin 1975).

${ }_{23}$ Kenneth H.Jackson (ed), Cath Maighe Léna, Mediaeval and Modern Irish Series 9 (Dublin 1938).

${ }^{24}$ Whitley Stokes (ed \& trans), 'In Cath Catharda: The Civil War of the Romans', in Ernst Windisch \& Whitley Stokes (eds), Irische Texte mit Wörterbuch, 4 vols (1880-1909) iv, 450-568.

2s Edward John Gwynn (ed \& trans), The Metrical Dindshenchas, 5 vols Royal Irish Academy Todd Lecture Series II (Dublin I924) iv, 336-39.

26 Charles Plummer (ed \& trans), 'Betha Mochuda', in Bethada Náem nÉrenn, 2 vols (Oxford I922) i, 29I-99.

${ }_{27}$ Edmund Hogan (ed \& trans), 'Incipit do Scélaib na nDruad', in The Irish Nennius from L. na Huidre and homilies and legends from L. Brecc. RIA Todd Lecture Series 6 (Dublin I895).

${ }_{28}$ George Calder (ed \& trans), Togail na Tebe: the Thebaid of Statius. The Irish Text (Cambridge 1922).

29 Whitley Stokes (ed \& trans), 'The Gaelic abridgment of the Book of Ser Marco Polo', ZCP I (I897) 245-73.

30 George Calder (ed \& trans), Imtheachta Eniasa: the Irish Eneid [being a translation, made before $A D$ I400, of the XII books of Vergil. ITS 6 (Dublin 1907).

31 Brian Ó Cuív, 'Lugh lámhfhada and the death of Balar Ua Néid', Celtica (1954) 64-66.

32 Lambert Mc Kenna (ed \& trans), 'Christ's Five Wounds', Aithdioghluim Dána, 2 vols. ITS 40, 4I (Dublini939-40) ii, 55 .

33 Eoghan Ó Neachtain, 'Tochmarc Fearbhlaide', Ériu 4 (I9I0) 47-67.

34 Paul Walsh, Beatha Aodha Ruaidh Ui Dhombnaill as Leabhar Lughaidh Ui Chléirigh: The Life of Aodh Ruadh Ó Dombnaill, transcribed from the Book of Lughaidh Ó Cléirigh, 2 vols ITS 44, 45 (Dublin 1948-1957). 
In the majority of attestations the translation, 'prophecy' or 'omen' is appropriate and the examples below demonstrate this. It is particularly striking that the Middle Irish texts, mostly translations from Latin, use célmaine where a visible physical sign is evident. In these cases some specialist knowledge is needed to correctly interpret the sign. Sometimes a supplicant has made an appeal or carried out a ritual but not always.

In Imtheachta Aniasa an invocation has been made to the gods which has resulted in a physical sign, a star, from heaven, and the author has chosen to use célmaine to express this manifestation or omen. (This text has been dated to the twelfth century). 35

In tan tra adconnairc Anachis in doghaillsi moir sin 7 in bron foraindhe, ba galar trom laissium inni sin 7 ba cunntabairt lais cid dogenad, in dul leo, no in anad, 7 tocbaid a lama 7 a rosc dochum nime 7 is ed roraid: 'A dei nime, tiged bar furtacht chugum, 7 nertaidh in comairli coir form. Tic dono in tan sin co hobond torand mor and, 7 tic do retla thaitnemach co soillsi dermair le do nim co ndesid for cleithi in tige i rabamar-ni co rosoillsigh coill slebi Ida. O 'dconnairc Anachis inni sin is ed roraid: 'Is maith in celmuine', ar se, is relta inchoisc eolais moir 7 seda conaire sut. Is intochta le.

(11. 595-605)

Now when Anchises saw that great trouble and our sorrow, that caused him great pain, and he was in doubt what he should do, whether to go with them or stay; and he lifted up his hands and his eyes to heaven saying: 'Gods of heaven, let your help come unto me, and strengthen the right counsel in me.' And then suddenly there came a great peal of thunder, and there came to him a bright star, accompanied by an exceedingly strong light from heaven, and it settled upon the rooftree of the house we were in, illuminating the forest of Mount Ida. When Anchises saw that thing, he said: 'Good is the omen' quoth he; 'yon is a star to indicate much guidance and a journey's course. We must go with it. ${ }^{36}$

The fifteenth-century century Incipit do Scélaib na nDruad has a description of the arrival of the Magi to visit the infant Jesus. A group of strangers, behaving in an extraordinary way, wearing unusual clothes approach the house where Jesus is. Joseph explains to Simeon what he thinks the men are doing:

${ }^{35}$ Erich Poppe, 'Textual authority and adaptation in "Christ's First Preaching" in the Leabhar Breac', in Elizabeth Boyle \& Deborah Hayden (eds), Authorities and adaptations: the reworking and transmission of textual sources in medieval Ireland (Dublin 2015) I59-84: 32; Brent Miles, Heroic saga and Classical epic in medieval Ireland. Studies in Celtic History 30 (Cambridge $20 \mathrm{II}$ ) 5I, 58.

${ }_{36}$ Calder, Imtheachta Aniasa, 38-39. 
Indar lium, a meic, ol se is celmaine druad ocus is methmerchurdacht dogniat uair ni berait oen choisceim cen fégad suas.

I fancy my son he said, that it is the omen art of Druids, and that it is soothsaying they are practising for they take not a single step without looking up. ${ }^{37}$

They explain to Joseph that they have been following a star, a physical sign, and are evidently using their knowledge to interpret its significance.

Can asa tuicebair-si sin?' ol loseph. 'Ni ansa són' ol siat, 'a beth in ar senlebraib 7 in ar sencribennaib o ré in c (het)fir uainn cusindiu. i. Secip tan atcifemis retlaind a macsámla so ós cind ar tíre dul lee secip conair nodicsed, ar ba comartha rig in domain hi.

Whence did ye understand that?', said Joseph. 'Not hard to tell is that,' said they, '(on account of) its being in our old books and old writings from the time of the first man of us till to-day, that whatever be the time we should behold a star like this over our land (we were) to go with it what way soever it would go, as it was a sign of the King of the world' ${ }^{38}$

Togail na Tébe is thought to be not later than thirteenth-century. ${ }^{39}$ In this case, physical signs are being presented to the Greeks, but they either ignore them or are incapable of interpreting them correctly:

Dala immorro na $n$ Grec rochomergedar reompo can suan can sadaili i llo $n$ [a] a n-aidchi. Et ger-ua imda derbairdeda doirrthi 7 figrad firuilc daib, ni rothoirmisc iad, 7 fa moidi fich fergi na firloech gach celmaine condtrachta dachuiread daib, no go rangadar co sruth siralaind sribuaine Assopus i tir na Tiauannda.

(11. 398-425)

As to the Greeks, however, they marched forward with no sleep, no rest by day or night. And though many were the sinister signs and presage of veritable evil to them, it did not check them; and the fury of the wrath of the true heroes was the greater at every omen of malediction that was sent to them, till they reached the ever-beautiful green-flowing river Asopos in the land the the Thebans. ${ }^{40}$

37 Hogan, 'Incipit do Scélaib na nDruad', 59. Hogan's translation uses 'druids' rather than 'magi', which would be more suitable for the context.

${ }_{38}$ Hogan, 'Incipit do Scélaib na nDruad', 6r.

39 Miles, Heroic saga and Classical epic, 5 I.

$4 \circ$ Calder, Imtheachta Aniasa, 174-75. 
In The Gaelic abridgment of the Book of Ser Marco Polo, a fifteenth-century text, the word célmaine appears three times, and in each case it is associated with wizards who use their knowledge to interpret omens correctly. In this occurrence the wizards have induced a sign by performing a ritual. Both célmaine 'omen' and fáitsine 'prophecy' are found close together here indicating, perhaps, that the author saw them as separate events:

7 doberar a ndraithi dia saigid, 7 frafraighid dib faitsine 7 celmaine in chatha nó cinnus no biath doib 7 do Preispiter Seon. Luidhset na druidh fora cliathaib fis, 7 rothoghairmset demhna 7 dei aerdh a na ndocum, 7 do berat bhoicshimbin ndimoir leo, 7 roscoiltset 7 do ronsat dá leth di, 7 doberat Preispiter Seon d'ainm for leth di 7 Sisim for in leth n-aill, 7 cuirid la draidecht 7 tuaichlecht di leth na simhne do comlunn fri araili, 7 beridh in leth fora tucsat Sisim buaidh. Triallait na draithi for cula cu Tartraidibh fá luth 7 ghairdechus: indar-leo is iat bidh choscrach isin cath.

And their wizards are brought to them, and they enquire of them the prophecy and omen of the battle, or how it should be to them and to Prester John. The wizards went on their hurdles of knowledge, and summoned to them demons and aerial gods; and they bring a huge bulrush, and they split it and made two halves thereof, and they name one of the halves Prester John and the other Sisimis; and by wizardry and cunning they cause the two halves of the rush to contend with each other; and the half which they named Sisimis wins the victory. The wizards go back to the Tartars in joy and gladness, (for) it seems to them that it was they who would be triumphant in the battle. ${ }^{41}$

But in the early examples, which include Blathmac, and in those later texts that are not translations, the meaning does not appear to be associated with a physical sign. These are the texts that will be addressed here below. The dominant theme in these texts is that of a message or communication being delivered by an intermediary, often in verse, within an otherwise prose text. If the word célmainde is not used in the text immediately preceding the piece of poetry then it is used within the first stanza. The poem is always directly addressed to a person.

The occurrence of célmaine in the poem Colum Cille co Día dom eráil, also called the 'Prayer of Adomnán', is curious because the syntax as well as the context is very close to that of the first occurrence in Blathmac.

\section{Columb Cille}

co Día domm eráil

hi tias - ni mos-tias -

${ }^{41}$ Stokes, 'Gaelic abridgement', 264-65. 
(tocud iar már,

mui mo chélmaine)

buidne co aingel airm

(ainm hui násadaig Néil,

ni súail snádud)

Sïone co harchangliu hÉil,

indingnaib Dé Athar,

etir comslechtaib cethri sen find fichet firien,

fo-chanat riched rig ruinig ruithnigthi;

núal nád ránic, nád rocma-

recht mui, mo Christ,

cumachtach col.

May Colum Cille

commend me to God

when I go - may I not go soon-

(after great good fortune,

it is mine, my prophecy)

to the place of the angel host

(the name of Niall's famous descendant

not small its protection)

to the archangels of God in Sion,

in the strongholds of God the Father,

among the ranks of the twenty-four fair justified elders

who praise the heaven of the mysterious, splendid King;

lamentation has not reached them, does not touch them -

it is mine by right, my Christ,

of my powerful sins. ${ }^{42}$

The possibility of a meaning 'reward', which would tie in with some of its usages in Welsh, could be considered in this poem and perhaps also in Blathmac l. 598.43 However, although this would work for the first occurrence of célmaine in Blathmac it does not for the other two.

In Talland Étair, a ninth-century text, Conchobar's messenger, Leborcham, travels daily from Emain Macha to Étair to supply Conchobar with food. ${ }^{44} \mathrm{Her}$ usual role is to convey information to Conchobar. At one point in the tale she travels to the women in Ulster to tell them how the battle has ended. The word

42 Clancy \& Márkus, Iona, 170.

43 Barrett, A study, 2 I3.

${ }_{44}$ Ó Dónaill Talland Étair, 45-46. 
célmaine is used in the preamble to and at the conclusion of this section: Is and sin trá luid Leborcham fo-thúaid riasint slúag co célmainiu do mnáib Ulad 'It was then therefore that Leborcham went northwards before the host with a célmaine for the women of Ulster' (11. II6-17). ${ }^{45}$ She addresses Mugain, wife of Conchobar, $A$ bé find forusta 'O fair dignified woman' (1. 131). ${ }^{46}$ She names the warriors and describes their feats and the wounds they have suffered. Then she concludes with the news that they are coming home except for those that have fallen. This section of the text is concluded with Is ed célmaine in sin ruc Leborcham do mnáib Ulad 'This is the célmaine that Leborcham had brought to the women of Ulster' (1. 175). ${ }^{47} \mathrm{Her}$ announcement is neatly sandwiched between the two occurrences of célmaine.

This poem from Metrical Dindshenchas describes how Fingen spends a night chanting with Rothníam, an otherworldly woman, which results in a célmaine. No obvious physical sign is described here, but perhaps some enlightenment or knowledge has been imparted from Rothníam to Fingin as a result of the chanting (Poem ${ }_{23} 3$ Druim Fingin II):

Tictis sund cecha samna ind rigan 's in rig-damna: scartais ria slóg co soilse, co cantais ceól con bith toirse.

Ba derb la mac Luchta ille, feib docuchta celmuine, atberad tria chabra a cind congebad Banba im-barr-find.

(11. 5-12)

Every Samhain-tide would the queen and the princely youth come hither; they would part from their attendants till daylight and chant an ever-doleful song. Thenceforth the son of Luchta was assured, as omens portended, that she would tell him by word of mouth that he should rule over the fair surface of Banba. ${ }^{48}$

The combination of the words célmaine and chabra in the third stanza of Druim Fingin II corresponds to the use of these words in Blathmac. Towards the end of the first Blathmac poem, he calls on Mary and uses the same word in his efforts to

${ }^{45}$ Ó Dónaill, Talland Étair, 47.

${ }^{46}$ Ó Dónaill, Talland Étair, 47.

47 Ó Dónaill, Talland Étair, 48.

${ }^{48}$ Gwynn, Metrical Dindshenchas, iv, 336-37. 
persuade her to come to him, con.roirem cobrai ma tú $(1.575)^{49}$ 'so that we, you and I, may hold conversation together'. There is an association between the célmaine and the cobrae in both poems.

Scéla Cano meic Gartnáin describes how the protagonist sees a vision of a wave, or a wave vision, which he interprets as an announcement of the death of Illann mac Scanlán. He utters a lay addressed to Búach and here the word célmaine occurs in the first stanza of the poem.

A mu Búach

aiges in tond frisin mbrúach

Illann mac Scanláin do guin

nibo célmaine inmain

$$
(11.385-89)^{50}
$$

O my Búach

who drives the wave against the bank, for the wounding of Illann mac Scanlán it was not a welcome célmaine.

Cath Maighe Léna is considered to be a composite of texts of differing ages. Célmaine occurs in a discussion as to the wisdom, or lack thereof, of continuing into battle: 7 gurbo contracht célmbaine do na curadaib and that was a cursed célmaine for the warriors' (1. 1058). .1 Their elders had been misled somehow. Further on in the tale there is a description of three grotesque females who approach Eoghan and deliver the message that he will die if he proceeds with the battle. In the text which precedes their lay the word célmaine is used twice by Eoghan, who dismisses them and their warning:

Oraib féin 7 ar Chonn bar célmuine' ar Eogan, 'i. bar n-aird-mes a n-aér, 7 bar corbad a crannaibh, 7 neimb bar célmuine ar clochaib, 7 ar tonnuib mara bar mi-rún.

Upon yourselves and on Conn your célmuine' says Eogan, 'that is, into the air your prophecy, and your corruption into the trees, and the poison of your célmuine on the stones, and on the waves of the sea your bad intentions.'52

49 Barrett, A study, 212.

so Binchy, Scéla Cano, I4.

${ }^{51}$ Jackson, 4I; Togail na Tebe has a similar phrase, although the order of the words is reversed, gach celmaine condtrachta (Calder, Togail na Tebe, 174), and is translated as 'every omen of malediction'.

$\$ 2$ Jackson Cath Maige Léna, 62 (11. 1607-161). 
The lay that follows could be a warning or a curse and it begins by addressing Eoghan and his army with the words: Sgél lim dúib 'I have news for you' (1. I6I5).53 In the poems of Blathmac and in Scéla Cano meic Gartnáin, the poems are all addressed to a particular person and all begin with the vocative case. In Cath Maighe Léna the verse begins with the introduction Sgél lim dúib. There is a formality associated with these announcements. In these cases the speaker has news of importance to disclose to the listener. Blathmac is addressing Mary and he seems to be delivering news to console her and reinforce the message that all is good with her son. The second instance of célmaine in Blathmac (1. 746) is similar to Cath Maighe Léna. Blathmac also makes use of the word scél, 'story' or 'news', in relation to the célmaine.

Ni scél n-eris deit in sé, is creiti a célmainde.

Is iar n-eiséirgiu Christ gil

at.chuäid dia apstalaib.

(11. 745-48)

This is no heretical tale for you,

the célmainde is to be believed.

It is after the resurrection of bright Christ

that he told it to his apostles. ${ }^{54}$

It is noteworthy that Blathmac emphasises here that his message is not heresy, indicating perhaps that célmainde can be sometimes linked with heresy. Blathmac was most certainly a cleric. The Bigotian Penitential states that ' $\mathrm{He}$ who dares to follow another doctrine beside the Scriptures, or a heresy, is a stranger from the Church'ss The Penitential of Finnian and the Penitential of Columbanus condemn the practice of magic by clerics: 'If any cleric or woman who practises magic have led astray anyone by their magic, it is a monstrous sin, but it can be expiated by penance.5. $T$ These guidelines perhaps demonstrate that some dabbling in occult ceremonies were at the very least considered possible. Blathmac seems to be determined to show that the source of his knowledge is not outside acceptable Christian behaviour.

In Stanza 19I he is unambiguously delivering a message to Mary.

Is ed mo chélmainde nglé:

is rído mac na nemdae,

s3 Jackson, Cath Maige Léne, 62.

s4 Barrett, A study, 216.

ss Ludwig Bieler (ed), The Irish penitentials, SLH 5 (Dublin 1963) 237 (vii) 2.

${ }_{56}$ Bieler, The Irish penitentials, 79, гог. 
is ai grian asa gel tlacht,

is ai a n-éscae n-étracht.

(11. 761-64)

This is my clear célmainde:

your son is king of the heavens,

his is the sun whose garment is bright,

his is the shining moon. ${ }^{57}$

A possible interpretation of the purpose of the presentation of Blathmac's poems as a pair is that a célmaine can be induced by observing a series of rituals. From the very beginning of the first poem the poet is explicitly inviting Mary to come to him: Tair cucum (1. I). Towards the end of the first poem he repeats this request, asking Mary to visit him so that they may converse and that he may keen Jesus's death with her. There are also references to vigils and fasting in the first poem which are often associated with visions of the other world. In stanzas I4O and I4I Blathmac requests from Mary that his poem, if used as a vigil prayer with fasting and with tears, will save the supplicant from Hell.

Cech óen diamba figel sé

fo lige ocus éirge,

ar imdidnad diänim tall

amail luirig co cathbarr,

Everyone for whom this is a vigil-prayer

at lying down and at rising,

for unblemished protection in the next world

like a breast-plate with helmet,

cách nod.géba do cach deilb

i troscud aidchi Sathairnn,

acht rob fo déraib cen meth,

a Maire, níb ifernach.

(11. 557-64)

everyone, of every shape, who recites it, fasting on Friday night, provided that it be with tears without fail, Mary, may he not be destined for Hell. ${ }^{58}$

57 Barrett, $A$ study, 217.

58 Barrett, A study, 212. 
The power of the lament and the process of lamenting in helping the grieving person move from one stage in life to the next are seen to be hugely beneficial and are evidenced by the rituals that are universally associated with the rites of passage surrounding death. Blathmac sees himself in the role of keener and facilitator. He blesses God in Stanza I35 for allowing him to make the keen.

Bendacht for Dia ro.hir dam

in coiniud do.futhracar.

Cech mac bethad cechlos sé

bid formach a chainetlae.

(11. 537-40)

A blessing on God who has granted me

the keen I wished for.

Every son of life who shall hear this,

his fine purity will increase. ${ }^{59}$

Perhaps the elemental power inherent in the lamenting process itself is seen as a gateway that can lead to some kind of visionary as well as healing experience. Lambkin compares what he calls 'the keen-visit sequence' in the story of Laisrén from the text called The Monastery of Tallaght with the two poems of Blathmac. The context there is that Laisrén, a recluse, was attached to Clonmacnoise. He wore no clothes and was free from sin. He stayed in the home of a student one night and slept on a cloak. He sees a carnal vision and gets up and begins to lament. He performs a vigil and recites the three fifties (the psalms). Then he falls into a trance and an angel comes to him with a message 'Be not sorrowful'. According to Lambkin:

The correspondence of this keen-visit sequence with Blathmac is striking and suggests a shared pattern of religious practice. The story of Laisrén supplies the suggestive additional detail that his keen resulted in a trance, during which the angel 'came to him'. If this detail is applied mutatis mutandis to Blathmac, it enables better sense to be made of how the two poems related to each other. ${ }^{60}$

The result of the execution of the lament and the vigil is a trance and a visitation by an angel who consoles Laisrén. It is not clear if he purposefully set out to produce the apparition when he commenced the prayer, but if not, it was a fortunate side

59 Barrett, $A$ study, 2 II.

${ }^{60}$ Brian Lambkin, 'Blathmac's Bithchuiniu: "Perpetual keening” and “Migration”', in The poems of Blathmac son of Cú Brettan: reassessments, I19-55: 129. 
effect. With reference to Blathmac, Lambkin is persuasive in pointing out that something similar has taken place and that célmaine may refer to:

... the 'visit' and 'conversation' (cobrae, diäbor) which has taken place mystically in the interval between the two poems, while the poet, like Laisrén, was in a trance. ${ }^{61}$

Also intriguing to read in John Carey's recent edition of the Early-Modern Irish Two poems on Saint Patrick's Purgatory is that St Patrick purposefully initiates a ritual with the objective of receiving an apparition:

Do baoi Patraic ag proicceapat 7 nirb ail le feruib Erenn creidemuin dó noco fechaidhis da suiluib corpurda fen nem 7 iffurann 7 co mberidis a rogha diob. Cinnis Patraic comurle do denum maille rena naomuib 7 rena clercidhuib uime-sin 7 is si comurle arar cinnadur-sin.i. lon a collann do leicen dib 7 beth ag athach 7 ag udhghuidhe go dicra dutrachtach fan aon nDia morcomachtach do taibsi 7 do taisbena[d] doib uime-sin. ${ }^{62}$

Patrick was preaching and the men of Ireland did not wish to believe him until they saw heaven and hell with their own bodily eyes, so that they could choose between them. Patrick determined to take council with the saints and clerics around him. And this is the council that they took: to renounce the food of their bodies, and to be praying for an apparition and revelation to them concerning that matter. ${ }^{63}$

While the word célmaine does not occur in these two examples, and despite the chronological gap, they are useful as a parallel to demonstrate that the practice of prayer, fasting and/or lamenting can be used to produce the conditions needed for an apparition and revelation.

At the beginning of the second poem, Blathmac refers explicitly to the keen that has been performed and I suggest that his appeal to Mary has led to an encounter of some kind with her which has resulted in consolation and also in the acquisition of knowledge or a revelation. The second poem is the message or célmaine of this revelation: Jesus is eternally alive and eight prophecies of the Old Testament prophets with regard to Jesus have been fulfilled to a large degree. These prophecies relate to his birth, circumcision, baptism, crucifixion, burial, resurrection, ascension and to the coming of the last judgment. Martin Mc Namara has pointed out that the final

${ }^{61}$ Lambkin, 'Blathmac's Bithchuiniu', I3I.

${ }_{62}$ John Carey 'Two poems on Saint Patrick's Purgatory', in John Carey, Emma Nic Cárthaigh \& Caitríona Ó Dochartaigh (eds), The end and beyond, medieval Irish eschatology (Aberystwyth 2014) 50I-25: 506.

${ }_{63}$ Carey, 'Two poems on Saint Patrick's Purgatory' 507. 
prophecy, the second coming, is the only one that has not yet come to pass. ${ }^{64}$ The signs before Doomsday occupy the next section of Blathmac's poem, followed by a list of martyrs whose deaths will be avenged. The final part of the poem contains a description of the Day of Judgement. ${ }^{65}$ The fulfilment of the first seven prophecies substantiates the conviction that the last one will also happen. With regard to the credibility of Blathmac's message the many references within the poem to John the writer of the Apocalypse are worth considering. There are many echoes of Revelations in the second poem: the Alpha and Omega (1. 84I), the serpent which smites the perverse old serpent (1.834), John and the vision in Patmos (1. 886), the command 'do not be afraid' (1. 892), the washing of robes in blood (1. 816).66

Blathmac is adding authority to his message by stressing that it has been related by one of Christ's faithful messengers, the one who has slept on his very bosom. It could even be suggested that he received the message directly from John in some kind of vision rather than in the more mundane way of reading the Book of Revelations. Caitríona Ó Dochartaigh points out that '[i]n common with his medieval contemporaries, Blathmac conflates John the Evangelist with John the writer of the Apocalypse'. She refers to the Irish epithet Eoin Bruinne 'John of the Bosom' which comes from the tradition found in many Irish texts of the beloved apostle leaning on Jesus's breast at the last supper. ${ }^{67}$ Blathmac's verse could be the earliest reference to that tradition:

In fer ad.chuäid in sé
is óen a thecht torise.
Is é Ión mac no.ssluindiu
con-atail fria fírbruinniu.

(11. 897-900)

The man who has told this, he is one of his faithful messengers.

John is the boy that I mention who has slept on his true bosom. ${ }^{68}$

As outlined above the word célmaine is associated with messages and revelations. It is possibly a signal to the audience as to what the content of the following text

${ }^{64}$ Martin McNamara, 'The (Fifteen) Signs before Doomsday in Irish tradition', in Miscellanea Patristica, Warszawskie Studia Teologiczne (Warsaw 2007) 223-54: 232.

os Barrett \& Stifter, 'Blathmac's stanzas', 42- 52.

${ }_{66}$ Barrett, $A$ study: 1. 841, 219; 1. 834, 219; 1. 886, 220; 1. 892, 220; 1. 816; 218.

${ }^{67}$ Caitríona Ó Dochartaigh, 'Devotional and liturgical themes in the poems of Blathmac', in The poems of Blathmac son of Cú Brettan: reassessments, 156-72: 164-65.

${ }_{68}$ Barrett, A study, 220. 
will be. It is also possible that the word célmaine which is used so prominently in the first stanza is a way of categorising the poem. Blathmac uses the names of many canonical medieval Irish tale types throughout the poems, as Lambkin has noticed. ${ }^{69}$ The occurrence of these words may display Blathmac's awareness of tale types and genre: tochmarc 'wooing' (1. 602), compart 'conception' (1l. 23, 386, 933), longas 'exile' (11. 85, 98), fingal 'kinslaying' (1l. 410, 980), aided 'violent death' (1. 247), fled 'feast' (11. 138,798$)$, fis 'vision' (1. 886), togal 'destruction' (1. 982).70

It is conceivable that célmaine is a word that describes a poem whose purpose is to deliver messages or a revelation. I suggest that Blathmac's use of the word célmaine in such a prominent place in the first stanza of the poem is comparable to his use of coiniud in the first poem. Additionally, its occurrence in other Irish texts of the same period in the first few lines of the verse or in the introductory text supports this hypothesis. After careful consideration of the possible purpose and usages of the word célmaine, I suggest that it be considered as a technical term for a particular type of poetry whose function is to present a revelation or message. The fact that only one long example of this kind of text survives does not detract from my argument. After all Blathmac's first poem is also the only surviving example of an Old Irish keen.

69 Brian Lambkin, 'The structure of the Blathmac poems', 76.

70 Barrett, A study: 1. 602, 213; 1. 23, 198; 1. 98, 207; 1. 933, 221; 1. 85, 200; 1. 98, 200; 1. 410, 208; 1. 980,$222 ; 1.247,204 ; 1.138,201 ; 1.798,218 ; 1.982,220$. 
